Article

\title{
Deciphering Corporate Governance and Environmental Commitments among Southeast Asian Transnationals: Uptake of Sustainability Certification
}

\section{Jean-Marc Roda ${ }^{1,2,3,4, *}$, Norfaryanti Kamaruddin ${ }^{2, \dagger}$ and Rafael Palhiarim Tobias ${ }^{2,3, \dagger}$}

1 CIRAD, UPR BioWooeB, 43400 UPM Serdang, Malaysia

2 Universiti Putra Malaysia, INTROP, 43400 UPM Serdang, Malaysia; E-Mail: faryanti@gmail.com

3 Univ Paris Diderot, Sorbonne Paris Cité, CESSMA, F-75205 Paris, France;

E-Mail: rpalhiarim@gmail.com

4 Forest Research Institute Malaysia (FRIM), 52109 Kepong, Malaysia

$\dagger$ These authors contributed equally to this work.

* Author to whom correspondence should be addressed; E-Mail: roda@cirad.fr; Tel.: +60176642703.

Academic Editors: Pablo Pacheco, George Schoneveld and Andrew Wardell

Received: 23 October 2014 / Accepted: 9 April 2015 / Published: 29 April 2015

\begin{abstract}
Promoting tropical forest sustainability among corporate players is a major challenge. Many tools have been developed, but without much success. Southeast Asia has become a laboratory of globalization processes, where the development and success of agribusiness transnationals raises questions about their commitment to environmental concerns. An abundance of literature discusses what determines the behavior of Asian corporations, with a particular emphasis on cultural factors. Our hypothesis is that financial factors, such as ownership structure, may also have a fundamental role. We analyzed the audited accounts of four major Asian agribusiness transnationals. Using network analysis, we deciphered how the 931 companies relate to each other and determine the behavior of the transnationals to which they belong. We compared various metrics with the environmental commitment of these transnationals. We found that ownership structures reflect differences in flexibility, control and transaction costs, but not in ethnicities. Capital and its control, ownership structure, and flexibility explain $97 \%$ of the environmental behavior. It means that existing market-based tools to promote environmental sustainability do not engage transnationals at the scale where most of their behavior is determined. For
\end{abstract}


the first time, the inner mechanisms of corporate governance are unraveled in agricultural and forest sustainability. New implications such as the convergence of environmental sustainability with family business sustainability emerged.

Keywords: Southeast Asia; oil palm; forest; transnationals; investment strategy; emerging markets; competitiveness; network analysis; network metrics; ethnic business; ownership structure

\section{Introduction}

A long history of legitimate concerns regarding the state and the sustainability of tropical forests has led global fora and governments to establish regulations, platforms and frameworks targeted towards helping tropical countries achieve sustainable management of their forests. Concomitantly, and at a much faster pace, private and civil society initiatives developed a large array of actions and tools. Most of them aimed to mobilize public opinion, which in the last two decades have been characterized by several spectacular activist events such as boycotts or targeted campaigns, often organized by non-governmental organizations. The same period also witnessed the unprecedented progression of private market regulation tools such as ecolabels and environmental certification schemes. All of these tools emerged from the dominant paradigm that buyers' preferences ultimately condition the behavior of companies. It does so theoretically by sanctioning unsustainable behaviors, or securing market premiums to "greener" and "fairer" products. Nevertheless, after years of implementation, the original intention to save tropical forests has largely failed [1,2]. Weak consumer demand in global, emerging markets and fragile public governance frameworks in many developing countries, and the fundamental role of corporate powers are mentioned as the main reasons for this failure $[3,4]$.

Southeast Asia exemplifies how globalization has changed the patterns of forestry, value-chains and trade, from the 1960s to the present. Initially, timber trade and various agricultural crops were considered as independent value-chains. Their interconnections are now better known. Since the last two decades, it has become common to link deforestation with globalization, transnational corporations [5] and the development of cash crops [6,7]. Among the rapid changes witnessed by Southeast Asia, is the development of agribusiness transnational corporations such as Olam, Wilmar and Sinar Mas, which started as Asian conglomerates but now play in the same global field with the giants of the sector known as the ABCD traders (Archer Daniels Midland, Bunge, Cargill, Louis Dreyfus) [8]. Other lesser-known Asian corporations such as Sime Darby, Ta Ann, WTK, Samling, etc., occasionally appear in the news when some non-governmental organizations publish reports about their environmental misdeeds, real or alleged, or investors such as the Norwegian Government Pension Fund Global (GPFG) announce decisions to divest $[9,10]$. These new transnational corporations operate in every continent and in all sectors, including forestry and timber trade. They connect Asian issues to the rest of the world, especially to Africa, through their global presence. These controversial issues include deforestation, land grabbing, environmental degradation, and food versus cash crops for various industrial uses, including bio-energy [11-13]. 
A body of literature highlights the fact that tropical deforestation may be substantially and increasingly driven by globalized industries and transnationals rather than by rural farmers. This literature also emphasizes the need to target strategic corporations [14]. Surprisingly, this body of literature does not delve into the mechanisms, drivers or determinants of transnationals and large business groups' actions and behavior.

Economic and management sciences have already explored in detail how the behavior of business groups and large corporations are vastly more complex than simply what buyers' preferences dictate to them. Building on earlier theories [15,16], the seminal works of Porter [17,18] in the 1980s showed how a complex system of interactions between the bargaining power of buyers and suppliers, threats of new raw materials and entrants, threats of new substitutes to products and services and finally, rivalry among firms, result in a vast array of possible and different corporate strategies and subsequent behaviors. Other research demonstrated that there is a powerful relationship between the ownership structure of big business groups and their behavior [19-22]. This means that the financial structure of a group, that is the topology of the network formed by its subsidiaries, has a major influence on the behavior of the group. This behavior has variants that may depend on the culture of the ultimate shareholders controlling the group, or the place in the world where the group has its base [23,24].

In the specific case of Southeast Asian conglomerates, much research has detailed their propensity to display an extremely complex and opaque structure, of interlaced cross-shareholdings. Their activities usually cover many different sectors, from agriculture and timber to logistics, property, banking, media and services. The high level of cross-shareholding allow them both to increase the ultimate control by one family, and to be extremely adaptable to policy and market changes, by quickly transferring their financial assets from sector to sector, according to the changes in market conditions [25]. Most literature has been preoccupied with the cultural aspects of these business networks, searching the reasons for their success in ethnic capitalism, Confucian values, or other overseas-Chinese cultural traits [26-30]. This would point to the importance of ethnic-business and cultural factors, but at the same time other authors also describe similar conglomerates and business groups in extremely different cultural contexts, such as Indian business networks and the case of the Olam group (where most of the managers and the family who controls the company are ethnic Indians) [31,32], or the Korean conglomerates known as chaebols [33,34] and Japanese conglomerates known as keiretsu [35]. All of these other Asian networks, are quite similar in structure, organization, flexibility, cross-shareholding and opacity, but obviously do not share the same culture as the ethnic Chinese groups. This calls for functional approaches, trying to understand what may be the factors beyond culture, nationality, ethnicity, etc. Similarly, many of these Asian business groups seem to be tightly controlled by one family, but not all of them. Much of the management literature also discusses how the issue of ownership helps to understand the behavior of business groups [20,36-40].

Some scholars have explored why corporations decide to obtain — or not—various types of environmental certification in the Western [41] or Southern [42] Hemisphere. However, apart from Rugman [43] who has worked on how western multinationals behave according to their ownership structure, there is a gap in the literature in understanding the mechanisms of corporate governance with respect to environmental commitments by transnationals. This paper aims to reduce this gap using Southeast Asian examples. Although social network analysis tools have been used for many years to describe network relationships between companies [44,45], recent progress in computing power allows 
the analysis of very large corporate networks to assess their degree of control over various economic or social factors [46,47]. A growing number of papers now explore quantitatively the behavior of large business groups through network metrics analyzed from their ownership or financial structure, compared to various behavioral criteria [48-50].

Using network analysis, we analyzed the ownership structures of a few Southeast Asian transnationals. We determined the topology of their network of subsidiaries, and compared it to their uptake of certification, as a proxy indicator of their environmental commitment. Our hypothesis is that the topology of their ownership structure might be as important for their environmental commitment as other external market factors.

Next section describes the collection of data on transnationals, their selection and the analysis of their audited accounts. It explains the use of network analysis on the web of subsidiaries and shareholders, and the use eco-certification as a proxy of environmental commitment. The main findings are that ownership structures reflect clear differences in flexibility, control and transaction costs, but not in ethnicities. Additionally, capital and its control, ownership structure and flexibility explain $97 \%$ of the environmental behavior. The discussion section draws the limitations of this work, elaborates on the possible effects of exposure to mass markets, and explores the implications for sustainability.

\section{Material and Methods}

\subsection{Selection of Transnationals and Analysis of Their Audited Accounts}

A number of transnationals are significant players in oil palm plantations, the timber trade and other tree plantations in Southeast Asia. These activities have sometimes been criticized by environmental groups. The key Southeast Asian agribusiness transnationals to be regularly cited in the news and non-governmental organization reports, are Wilmar, Sinar Mas [51], Sime Darby, Olam [52], Ta Ann, and WTK [51,53,54]. We experienced difficulties in reconstructing the network of companies of Wilmar, a Singapore-listed group that belongs to the bigger Kuok conglomerate based in Hong Kong, and Sinar Mas group (most of the Indonesian audited accounts were not easily available within the time frame of the study). However, we managed to collect extensive data about the companies involved in Olam, Sime Darby, Ta Ann and WTK transnationals for the year 2010. We started with an analysis of the audited accounts of these groups, available at the Singapore and Kuala Lumpur stock exchanges. From there, we reconstructed step by step the ownership structure, by collecting the financial information of each company within the network, providing its own owners and subsidiaries, to establish the organizational boundaries of each transnational. We identified 931 major companies and legal entities constituting these four transnationals, regrouped in Table 1 with the listed capital and the nature of ownership of each transnational to highlight their key differences. 
Table 1. Financial characteristics of the data set, in 2010.

\begin{tabular}{|c|c|c|c|c|c|c|c|}
\hline \multirow[b]{2}{*}{ Transnational } & \multirow{2}{*}{$\begin{array}{l}\text { Number of } \\
\text { Companies }\end{array}$} & \multirow{2}{*}{$\begin{array}{c}\text { Market } \\
\text { Capital } \\
\text { (Million } \\
\text { US \$) }\end{array}$} & \multicolumn{3}{|c|}{ Repartition of Ownership } & \multirow{2}{*}{$\begin{array}{c}\text { Diversification } \\
\text { Investment } \\
\text { Strategy }\end{array}$} & \multirow{2}{*}{$\begin{array}{c}\text { Ethnicity of } \\
\text { Ultimate } \\
\text { Controllers }\end{array}$} \\
\hline & & & Family & Government & Others & & \\
\hline WTK & 78 & 70 & $47.86 \%$ & $1.69 \%$ & $49.55 \%$ & Related & Chinese \\
\hline Ta Ann & 101 & 90 & $50.25 \%$ & $9.36 \%$ & $40.39 \%$ & Related & Chinese \\
\hline Olam & 172 & 1680 & $22 \%$ & $14.40 \%$ & $63.60 \%$ & Related & Indian \\
\hline Sime Darby & 580 & 1820 & $0 \%$ & $67.86 \%$ & $32.14 \%$ & Unrelated & - \\
\hline Total & 931 & 3660 & & & & & \\
\hline
\end{tabular}

The ultimate controller of Sime Darby is the government of Malaysia, and the group originates from a British company. Therefore its ultimate controller has no ethnicity.

WTK Holding Berhad is the flagship company of the WTK group. It was established in 1940 in Sibu, Malaysia, in order to obtain forest concessions and licenses to trade in logs. Three sons of the late Wong Tuong Kwuong head the group: Wong Kie Nai, Wong Kie Chie and Wong Kie Yik. They own the majority of shares and they also manage the group. WTK Holding Berhad has subsidiaries operating throughout Asia, and the USA. WTK's main focus is timber log extraction and sawn timber and plywood production. The principal activities of the subsidiaries are: Manufacturing and sale of veneer, plywood, sawn timber and logs; trading in tapes, foil and papers; reforestation; general and commission agent; property investment and car park operation.

Ta Ann Holding Berhad is the flagship company of the Ta Ann group. It was founded in 1980 in Kuching, Malaysia, with connections to Sarawakian politicians led by Datuk Wahab Bin Haji Dolah and Datuk Abdul Hamed Bin Haji Sepawi. Dato Wong Kuo Hea and his family control the group. The first company was a trading company and started timber extraction from forest concessions located in Sarawak. The main activities of Ta Ann Holding Berhad are in palm oil, timber trading, and manufacturing of plywood and wood products. Ta Ann subsidiaries operate in Asia and Oceania. Three main persons control the group: Dato Wong Kuo Hea, Datuk Abdul Hamed Bin Haji Sepawi and Datuk Wahab Bin Haji Dolah. The observations, confirmed by subsequent analysis, showed that Dato Wong Kuo Hea is the main player in the network, and that he is the ultimate controller of the group through the shares retained by his relatives.

Olam International Limited is the flagship company of the Olam group. It is a general agriculture trading company with headquarters in Singapore. The Kewalram Chanrai group, another large group of companies created and controlled by the Chanrai family, founded Olam in 1989, with Sunny Verghese, an Indian employee of the Kewalram Chanrai group as its main shareholder. Originally operating in textiles, the diversification of the Chanrai group started in the years 1904-1910 from British India to many British colonies in Asia and East Africa. Chanrai has investments in various sectors, and created sub-groups such as Olam, Afri-ventures, Pt Kewalram, and Redington. Olam now has subsidiaries in Europe, Latin America, Africa, and throughout Asia. The group claims to have specific know-how for operating in countries generally considered risky for investors, including Sierra Leone, Ghana, and Nigeria, among others. Sunny Verghese, Narain Girdhar Chanrai and Rangareddy Jayachandran control Olam. 
Sime Darby Berhad is the flagship company of the Sime Darby group. It was formed in 1910 by European owners in the (then) British colony of Malaya, for rubber and cocoa, and later oil palm plantations. In the late 1970s Malaysian investors acquired half of the equity. In the 1980s, the group became a wholly Malaysian-owned company when the Malaysian government acquired supplementary shares through Permodalan Nasional Berhad (PNB), Malaysia's biggest fund management company. The group was initially listed at the London Stock Exchange, and was subsequently relisted at the Kuala Lumpur stock exchange. In 2007, Sime Darby and two other agribusiness groups (Guthrie Berhad and Golden Hope) merged into Synergy Drive. It was then renamed as Sime Darby Berhad, and has become one of the major Malaysia-based transnationals. The group is involved in five core sectors: Plantations, property, industrial, motors and energy \& utilities. It has subsidiaries in Asia, Africa, and Europe.

\subsection{Network Analysis}

To analyze this data, we applied network analysis that quantifies and qualifies the relationships among the players, according to their number, direction, intensity, and with respect to the rest of the players of a group, their own interactions, and the structure of the whole system [47]. Specific software exists to compute social analysis and network metrics, such as Pajek, Gephi, and Cytoscape. $[45,55,56]$. We used Cytoscape here [56] for its data handling capabilities, which makes it convenient to transfer financial and ownership information from our data set. Cytoscape also has good visualization capabilities.

There is usually a separation between ownership and real control in Southeast Asian transnationals [25]. Within the complexity of cross-shareholdings of a transnational, it might be difficult to identify the ultimate controlling shareholders. One solution is to compute all the percentages of ownership from a subsidiary to all its owners. For example, company A might own only $29 \%$ of company D, but still with A being indirectly the ultimate controller of D because A directly controls B who directly controls D (see Figure 1, adapted from Tekusova [57]). Usually simple threshold rules, variable according to the specific financial regulations of the country of incorporation, determine when a company gets a direct control over a subsidiary. For example the threshold can be $50 \%$ in one country, and $30 \%$ in another one. In our data, the same $50 \%$ threshold of ownership was applied to all companies to determine the direct control rights.

Alternatively, the degree of influence of all the companies over the transnationals and their various functions and roles, can be deduced from several network metrics, according to different criteria (ownership control, information flow, speed of decision for flexibility, etc). The main categories of these metrics are various kinds of centrality measures, as well as centralization, clustering and other network topology measures. Most of the meaning of these network metrics can be obscure when applied to networks of companies, thus we have translated them into economic terms. For example, the betweenness centrality of a company is the number of hierarchic shortest lines passing through one company, compared to all the other shortest lines. It is an index of the real control exerted by one company over the other companies within the transnational. In economic terms, it is a shareholding betweenness index, and it is a measure of the average corporate control within the transnational or among its companies. This particular index allows the identification of the ultimate controlling 
companies of the group, either through their indirect ownership, or through the flow of decisions, which have to go through them. Some of the metrics apply at the level of the player (company in our case) or at the level of the group (transnational in our case), or even sub-groups such as cliques and sub-cliques $[58,59]$. Simple metrics that provide a general description of the transnationals include the number of companies, number of direct ownership links, size of the transnational in terms of maximum or successive ownership links, and intensity of cross-shareholdings. More complex metrics describe the repartition of companies and the topology of their network.
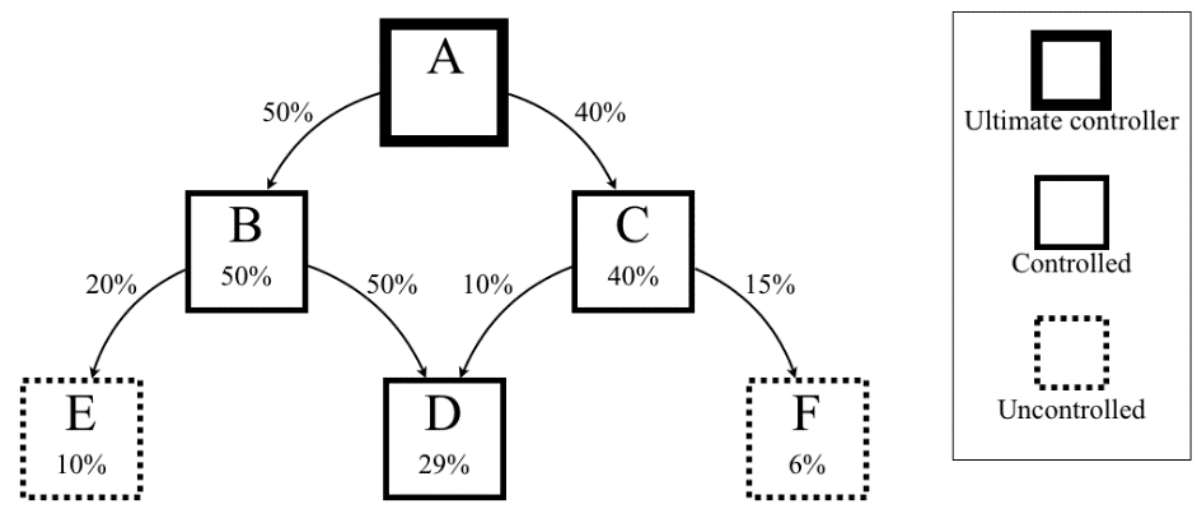

Figure 1. Simple ownership structure with ultimate shareholding controller, and controlled subsidiaries. The percentages attached to each ownership arrow represent the proportion of ownership of one company by another company. The percentages within the box represent the real ownership by company A, which might be lower than the real control.

The group-level metrics, which have some meaning at the scale of a transnational are listed in Table 2, with their economic meaning and associated comments. These metrics can also be computed at the company level, with a few variants according to the direction of the ownership links.

Table 2. Network metrics and their meaning for ownership structures in economic terms. (The equations of the networks metrics were taken from [43-47] and from the supplementary materials of [60]. The economic meaning and comments are by the authors).

\begin{tabular}{|c|c|c|c|c|}
\hline Network Metrics & Equation & & Economic Meaning & Comment \\
\hline $\begin{array}{l}\text { Network clustering } \\
\text { coefficient }\end{array}$ & $\operatorname{Avg}\left(\frac{e_{j}}{n_{j}\left(n_{j}-1\right)}\right)$ & (1) & $\begin{array}{l}\text { Average } \\
\text { Cross-shareholding } \\
\text { coefficient }\end{array}$ & $\begin{array}{l}\text { (1) is an average of the clustering indices of all the companies of } \\
\text { the ownership structure. This coefficient expresses the average } \\
\text { degree of cross-shareholding within the shareholder structure. }\end{array}$ \\
\hline $\begin{array}{c}\text { Average shortest } \\
\text { path length }\end{array}$ & $A v g\left(\sigma_{i k}\right)$ & (2) & $\begin{array}{c}\text { Average ownership } \\
\text { tier }\end{array}$ & $\begin{array}{l}\text { (2) is the average shortest distance between two companies within } \\
\text { the ownership structure. It is similar to the average tier rank of } \\
\text { subsidiaries, but it applies both vertically and horizontally. }\end{array}$ \\
\hline$\%$ of shortest paths & $\frac{\sum_{i \ldots k}\left(\sigma_{i k}\right)}{(C)^{2}}$ & (3) & Co-management index & $\begin{array}{c}\text { Expressed as a \% or as a fraction, (3) is the number of shortest } \\
\text { ownership lines over the maximum theoretical possible } \\
\text { number of direct shareholdings. }\end{array}$ \\
\hline
\end{tabular}


Table 2. Cont.

\begin{tabular}{|c|c|c|c|c|}
\hline Network Metrics & Equation & & Economic Meaning & Comment \\
\hline $\begin{array}{l}\text { Reciprocal of } \% \text { of } \\
\text { shortest paths }\end{array}$ & $1-\frac{i \ldots k}{(C)^{2}}$ & (5) & Hierarchy index & $\begin{array}{l}\text { Expressed as a \% or as a fraction, (5) is the reciprocal of the } \\
\text { number of shortest ownership lines over the maximum } \\
\text { theoretical possible number of direct shareholdings. } \\
\text { The higher it is, the more hierarchical the ownership structure } \\
\text { is. The structure forms pyramids of tiered subsidiaries. } \\
\text { The structure tends to look like a pyramid or a star. }\end{array}$ \\
\hline Geodesic distance & $\sigma_{i k}$ & (6) & Tier & $\begin{array}{l}\text { (6) is the number of successive ownership links between } \\
\text { two companies }\end{array}$ \\
\hline Number of nodes & $C$ & $(7)$ & Number of companies & (7) is the size of the group, in number of companies. \\
\hline
\end{tabular}

(8) is the shortest ownership lines are the smallest ownership distance (horizontally or vertically) between two given

$\begin{array}{lll}\text { Number of } & \sum_{i \ldots k}\left(\sigma_{i k}\right) \quad \text { Number of shortest } \\ \text { shortest paths } & \text { ownership lines }\end{array}$
companies within the ownership structure. There are a limited number of these shortest ownership lines, which is always a fraction of the maximum theoretical possible number of direct ownership pairs. The smaller the number of ownership lines, the more hierarchical is the ownership structure.

\begin{tabular}{|c|c|c|c|c|}
\hline Network diameter & $\Lambda_{i k}$ & (9) & $\begin{array}{c}\text { Ownership structure } \\
\text { diameter }\end{array}$ & $\begin{array}{l}\text { (9) is the largest distance between two companies within the } \\
\text { ownership structure. It is similar to the largest tier rank of } \\
\text { subsidiaries, but it applies both vertically and horizontally. }\end{array}$ \\
\hline $\begin{array}{l}\text { Betweenness } \\
\text { centrality }\end{array}$ & $\sum_{i \neq j \neq k} \frac{\sigma_{i k}(j}{\sigma_{i k}}$ & $(10)$ & $\begin{array}{l}\text { Shareholding } \\
\text { betweenness }\end{array}$ & $\begin{array}{l}\text { (10) is the number of shortest ownership lines passing through } \\
\text { one company, compared to all the shortest ownership lines. } \\
\text { It is an index of the real control exerted by one company over } \\
\text { the ownership structure. }\end{array}$ \\
\hline Closeness centrality & $\frac{1}{\operatorname{Avg}(}$ & (11) & $\begin{array}{l}\text { Shareholding } \\
\text { closeness }\end{array}$ & $\begin{array}{l}\text { (11) is the reciprocal of the average shortest distance between } \\
\text { two companies within the ownership structure (reciprocal of B } \\
=\text { Average ownership tier). This index expresses how fast } \\
\text { board decisions or strategic adaptations can be transmitted or } \\
\text { propagated within the ownership structures. }\end{array}$ \\
\hline Stress centrality & $\sigma_{i k}$ & (13) & Shareholding stress & $\begin{array}{l}\text { (12) is the absolute number of shortest ownership lines passing } \\
\text { through one company. It is a index of the time taken to apply a } \\
\text { decision to the group, or of the internal transaction cost. }\end{array}$ \\
\hline
\end{tabular}

Where $i j k$ are companies; $C$ is the total number of companies, $n$ is the number of neighbours of $i, e_{i}$ is the number of connected pairs between all neighbors of $i, \sigma_{i k}$ is the shortest distance between $i$ and $k$, $\Lambda_{i k}$ is the largest distance between $i$ and $k, \sigma_{i k}(j)$ is the shortest distance between $i$ and $k$ and passing through company $j$. 


\subsection{Eco-Certification as a Proxy of Environmental Commitment}

In order to understand if the corporate structure has an impact on the company's commitment to adopt sustainable practices, we adopted two key certification schemes of sustainable forest management (Forest Stewardship Council-FSC), and of sustainable oil palm plantation management (Round Table on Sustainable Palm Oil-RSPO) as criteria of commitment (i.e., "minima"), see Table 3. This study is not in a position to judge the effective sustainability of such eco-certification and associated practices in the field, or to assess if the existence of such certification schemes represents green washing $[61,62]$ or real commitments by the transnationals studied. These transnationals also invest in other economic sectors such as real estate, which are not directly relevant to such environmental schemes. On this particular matter, the construction sector eventually possesses a suite of green building indexes [63], but remotely connected to forest and palm oil certification schemes. We selected all the relevant sectors and noted which companies of which groups were certified at the time of the study and under which scheme. We also noted all the companies of the relevant sectors, with ascending or descending ownership links with the certified companies, but which were not certified themselves.

A factorial map was built, with each company of the transnationals being associated with the presence or absence of such certification schemes. As such, we consider the presence or absence of various environmental certificates, as a proxy indicator of a certain level of environmental commitment, be it genuine or not. In addition, the data set also associates to each company its various network metrics with their economic meaning, as well as the country of origin of the transnational, the eventual ethnic character of the management of the transnational, and the transnational financial specificities such as its diversification and investment strategy, as deduced from audited accounts. Independently of a possible normative criticism of the quality of the existing eco-certificates to assess the environmental commitment, this data set allows us to explore if some ownership structure mechanism, or other economic factors, can be linked, at least to some degree, to nominal environmental commitment. We used FactoMineR, a package of the statistical software R, in order to conduct supervised and unsupervised statistical explorations of the links between these factors, and to determine if some specific factors have more influence over the uptake of eco-certification.

Table 3. Nature of environmental commitment, by transnational.

\begin{tabular}{cccccc}
\hline Transnational & $\begin{array}{c}\text { Forest Stewardship } \\
\text { Council (FSC) }\end{array}$ & $\begin{array}{c}\text { Pan European Forest } \\
\text { Certificate (PEFC) }\end{array}$ & $\begin{array}{c}\text { Any Forest } \\
\text { Certificate }\end{array}$ & $\begin{array}{c}\text { Round Table on } \\
\text { Sustainable Palm } \\
\text { Oil (RSPO) }\end{array}$ & $\begin{array}{c}\text { Any Forest or Palm } \\
\text { Oil Certificate }\end{array}$ \\
\hline WTK & - & - & - & - & - \\
Ta Ann & - & Yes & Yes & - & Yes \\
Olam & Yes & - & Yes & Yes & Yes \\
Sime Darby & - & - & - & Yes & Yes \\
\hline
\end{tabular}

WTK has no certification. 


\section{Results and Discussion}

\subsection{Ownership Structures}

The visualization of the ownership structure of the transnationals of this study, and the computation of their ultimate shareholders is represented in Figure 2. Ta Ann and Sime Darby are connected through a common shareholder, the Malaysian government. This shareholder controls Sime Darby, but is an extremely minor shareholder of Ta Ann, which is controlled by the Wong family. We found that the size of the transnationals in terms of number of companies is not significant to clearly discriminate them. Conversely, some network metrics enabled us to neatly classify the transnationals into two groups. WTK, Ta Ann, Olam belong to the group with indexes denoting intertwined networks, in comparison to Sime Darby which displays an extreme hierarchical structure, see Table 4. The average ownership tier and the shareholding degree respectively measure how many subsidiaries and how many shareholders a typical company has within the transnational. For example, a Sime Darby company has on average only one shareholder, and most of the time has no subsidiaries. This denotes a very pyramidal and hierarchical topology with almost no transversal ownership links.

In other words, as an extremely hierarchical transnational with almost no cross-shareholdings despite counting three to seven times more companies, Sime Darby stands apart from the other transnationals, which are smaller but are twenty to eighty times more interconnected. The cross-shareholding coefficient directly measures how the ownership is interlinked. Here, WTK, Ta Ann, and Olam are exemplars of what the literature describes as overseas-Chinese conglomerates, with multiple cross-shareholdings that make them opaque, but also extremely flexible. Indeed, the more numerous the cross-shareholdings, the easier it is for a conglomerate to quickly move its financial assets from one sector to another one, according to economic change or perturbations [25,64-67]. Network analysis helps to visualize and to quantify emerging properties from specific organizational patterns. One can then pose the question what are the functional reasons for the high level of cross-shareholding within Asian transnationals? The same literature mentions the high degree of control by the family, along with a form of deconcentration of the management to trusted individuals, which is theoretically necessary to ensure the flexibility and responsiveness of transnationals. Our results confirmed this theory and provided a measure of it, with the comparison of shareholding betweenness and shareholding stress. Figure 3 illustrates the emergence of such dimensions, their visualization, and the ranking of corporations according to them. The first is an index of how much control a typical company has over the rest of the transnational. The higher the control, the more deconcentrated is the management of the companies. Consequently the transnational is more adaptable. The second shows how many boards should meet on average for a decision to be implemented in each company of the group. It is a measure of the decision delay within the transnational, or an indirect measure of the transaction cost of its management. The higher it is, the slower the decision process of the transnational, and consequently the less responsive it is. Figure 3 shows that for the same level of decision delay or transaction cost companies such as WTK, Ta Ann, and Olam benefit from having significantly more control over the rest of their own business group. Conversely, for the same level of control over the rest of the business group, a company from Sime Darby has a longer decision delay, or a higher transaction cost. 
We were intuitively expecting to observe different ownership structures for transnationals controlled and managed by ethnic Chinese, compared to those controlled and managed by ethnic Indians. To our surprise, this was not the case. We found that there is no difference in ownership structure between ethnic Indian management and ethnic Chinese management, see Table 5. However, the ownership structures associated with both ethnic Indian and Chinese management are very different from the ownership structure with government and technocratic management (Sime Darby). The meaningful factors are then, respectively, family versus government control, intertwined structure versus hierarchical structure, or related investment diversification versus unrelated investment diversification. Of course all family control, cross-shareholdings, and related investment diversification are typical of overseas-Chinese businesses, according to the literature. Nevertheless these characteristics are also typical of other kinds of Asian business conglomerates. Our results thus confirmed the studies that emphasize the non-ethnic character of the functional side of family controlled businesses within diasporic and transnational communities [68-70].
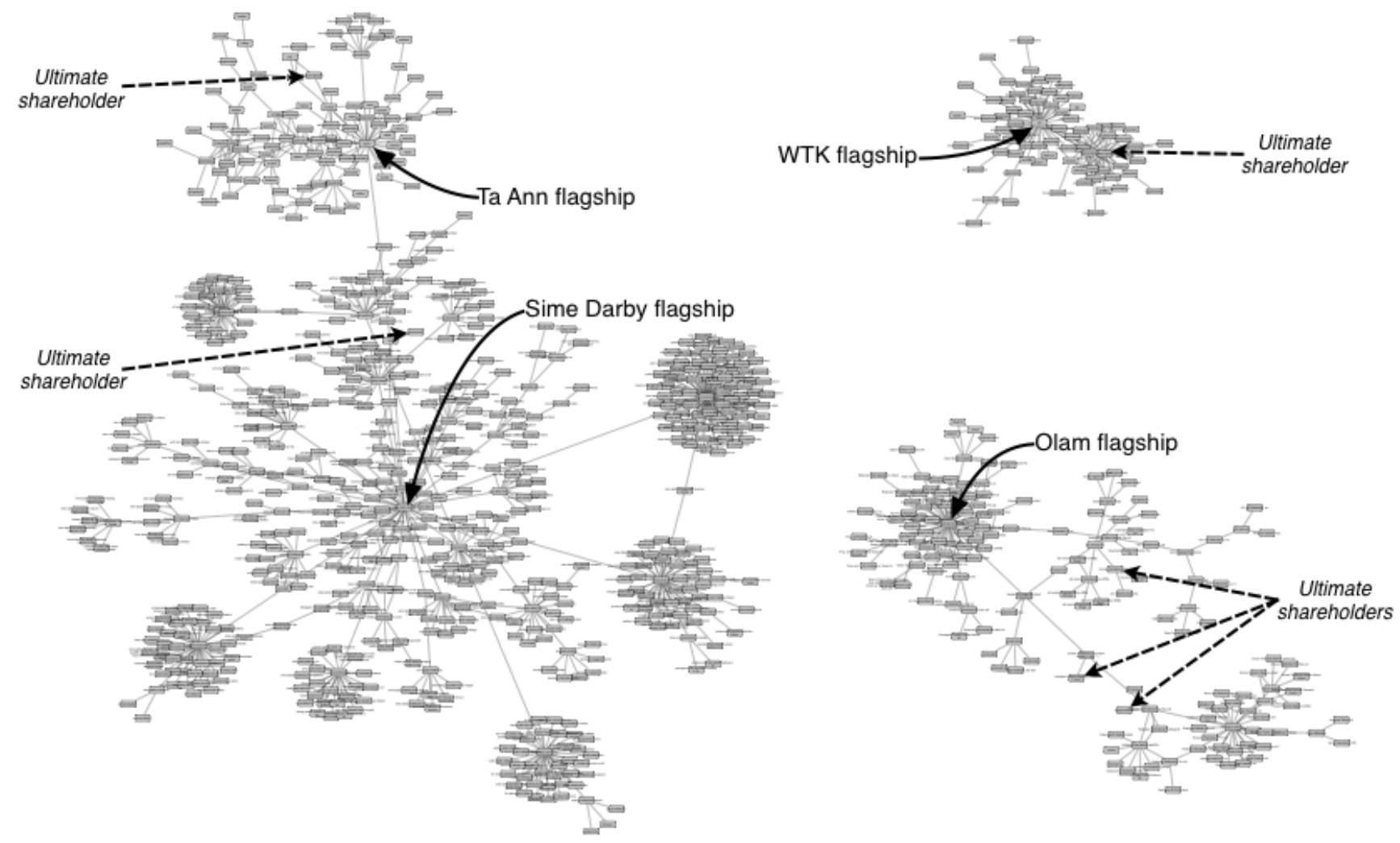

Figure 2. Ownership structures of WTK, Ta Ann, Olam, and Sime Darby. 


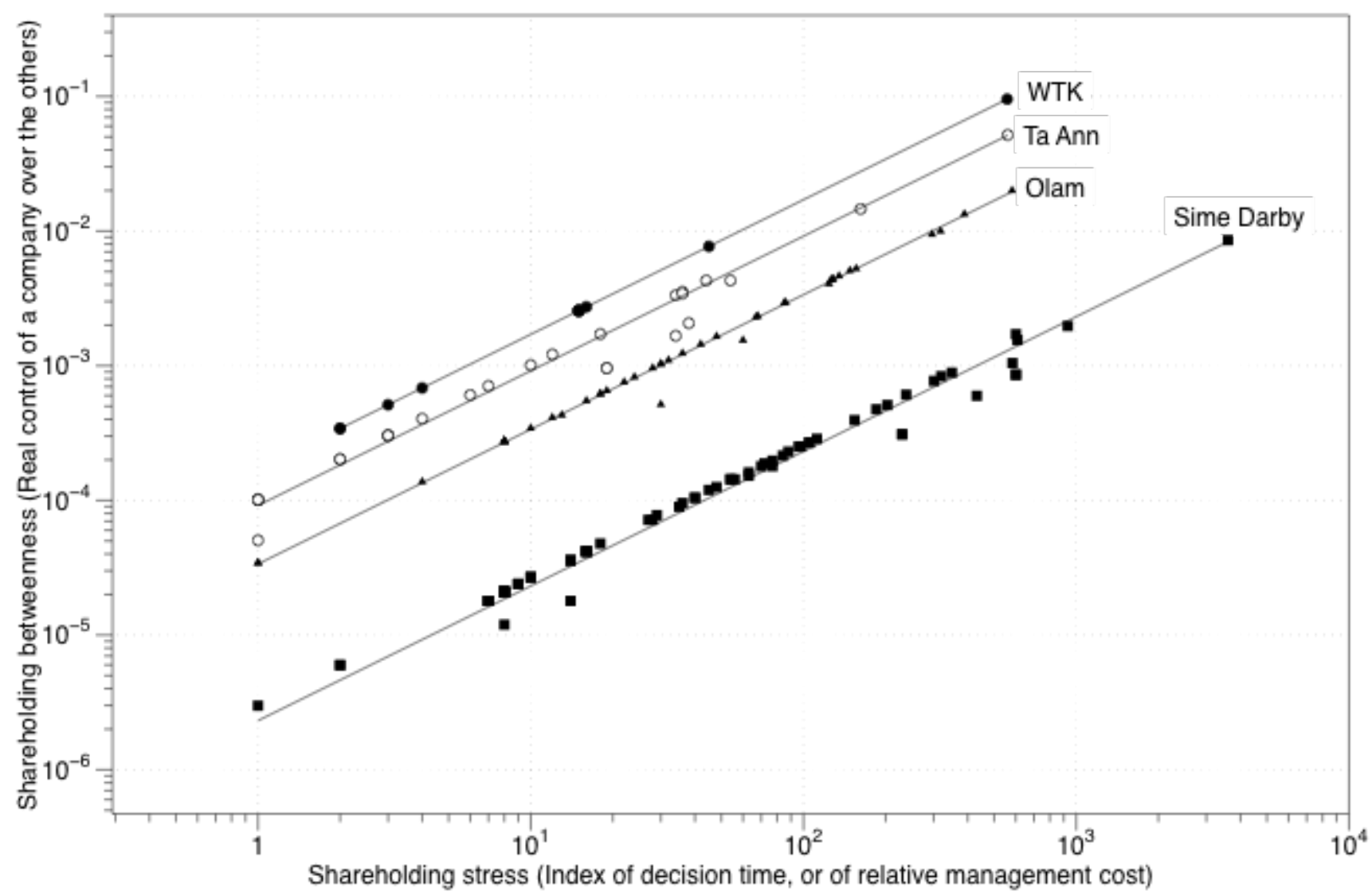

Figure 3. Flexibility and responsiveness of companies according to their affiliation to WTK, Ta Ann, Olam and Sime Darby.

Table 4. Anova of companies identify intertwined ownership structures.

\begin{tabular}{|c|c|c|c|c|c|c|c|c|c|}
\hline \multirow{2}{*}{ Metrics } & & \multirow{2}{*}{ WTK } & \multirow{2}{*}{ Ta Ann } & \multirow{2}{*}{ Olam } & \multirow{2}{*}{ Sime Darby } & \multicolumn{2}{|c|}{ TSS } & \multirow{2}{*}{$F$ value } & \multirow{2}{*}{$\operatorname{Pr}(>F)$} \\
\hline & & & & & & Group & Res. & & \\
\hline & $\mathrm{N}$ & 78 & 101 & 172 & 580 & & & & \\
\hline Cross-shareholding & Mean & 0.019 & 0.023 & 0.078 & 0.001 & 0.808 & 5.838 & 42.77 & $<2 \times 10^{-16}$ \\
\hline Coefficient & SD & 0.066 & 0.079 & 0.167 & 0.010 & & & & $* * *$ \\
\hline Average ownership & Mean & 0.545 & 0.782 & 0.616 & 0.206 & 45.4 & 542.7 & 25.82 & $<4.82 \times 10^{-16}$ \\
\hline Tier & SD & 0.841 & 0.938 & 1.126 & 0.563 & & & & $* * *$ \\
\hline Shareholding & Mean & 1.435 & 1.515 & 1.424 & 1.056 & 34.9 & 681.5 & 15.8 & $4.99 \times 10^{-10}$ \\
\hline Degree & SD & 1.717 & 1.741 & 0.802 & 0.267 & & & & $* * *$ \\
\hline Shareholding & Mean & -6.134 & -7.188 & -6.815 & -9.407 & 287.8 & 393.0 & 40.3 & $<2 \times 10^{-16}$ \\
\hline Betweenness & SD & 1.483 & 1.681 & 1.458 & 1.555 & & & & $* * *$ \\
\hline Hierarchy index & $\%$ & $89 \%$ & $93 \%$ & $96 \%$ & $99 \%$ & - & - & - & - \\
\hline
\end{tabular}

With degree of freedom for group $=3$ and for residuals $=926$. $* * *$ : extremely significant. No $\mathrm{F}$ Value can be computed for the Hierarchy index. 
Table 5. Significance of various business factors.

\begin{tabular}{cccccc}
\hline Ethnicity of Management & $\boldsymbol{N}$ & Estimate & SE & $\boldsymbol{t}$ value & $\operatorname{Pr}(>|\mathbf{t}|)$ \\
\hline Indian-Chinese & $172-179$ & -0.06295 & 0.08188 & -0.769 & 0.719 \\
None-Chinese & $579-179$ & -0.47227 & 0.06558 & -7.201 & $<1 \times 10^{-5} * * *$ \\
None-Indian & $579-172$ & -0.40932 & 0.06659 & -6.147 & $<1 \times 10^{-5 * * *}$ \\
\hline \multicolumn{6}{c}{$* *$ extremely significant. }
\end{tabular}

\subsection{Capital and Its Control}

A Principal Component Analysis was performed on the 931 companies of the data set, with ownership structure, financial factors and a proxy for environmental commitment as variables. Environmental commitment factors such as various types of certification, were set as "supplementary variables", in order to measure their correlation with the other factors. In Principal Component Analyses, "supplementary variables" do not contribute to the computation results for the other variables. As such, their absence would not change the results for the other variables. However their correlations with respect to the other variables are computed. To put some variables as "supplementary", allows us to measure how the main variables, or the dynamics that influence them, influence the "supplementary variables". A high correlation for the supplementary variables would denote that they are highly influenced by the processes described by the main variables. Figure 4 presents the factor map for Dimensions 1 and 2, which explains close to $50 \%$ of the variability. The main statistical results of the principal component analysis are detailed in Table 6. Dimensions 1 and 2, respectively, explain 29 and $20 \%$ of the variability. They describe how each group of companies varies in ownership structure, and how their companies are discriminated by various financial and economic factors. Dimension 1 ranks the business groups according to their listed capital and degree of government involvement in their ownership structure. It contrasts investment strategies of related diversification to unrelated diversification. It also highlights Sime Darby group, a typical non-flexible group. This group appears heavily constrained by its lack of cross-shareholdings and its overwhelming government involvement. The companies also display different level of uptake of certification along this dimension. However, with this data set, it is impossible to disentangle the respective effects of the size of capital, of government involvement, and of the necessities of flexibility. Dimension 2 ranks the business groups according to their relative number and proportion of subsidiaries, and to their level of decision delay or internal transaction cost. The fact that this dimension sets apart the two big corporations from the two smallest, suggests that capital is, nevertheless, a major factor. Indeed, this dimension also ranks the companies according to their uptake of certification, producing a nice diagonal pattern of the companies across the graph of these 2 dimensions. Dimension 3 mainly isolates the ownership structure specificities of Olam. 


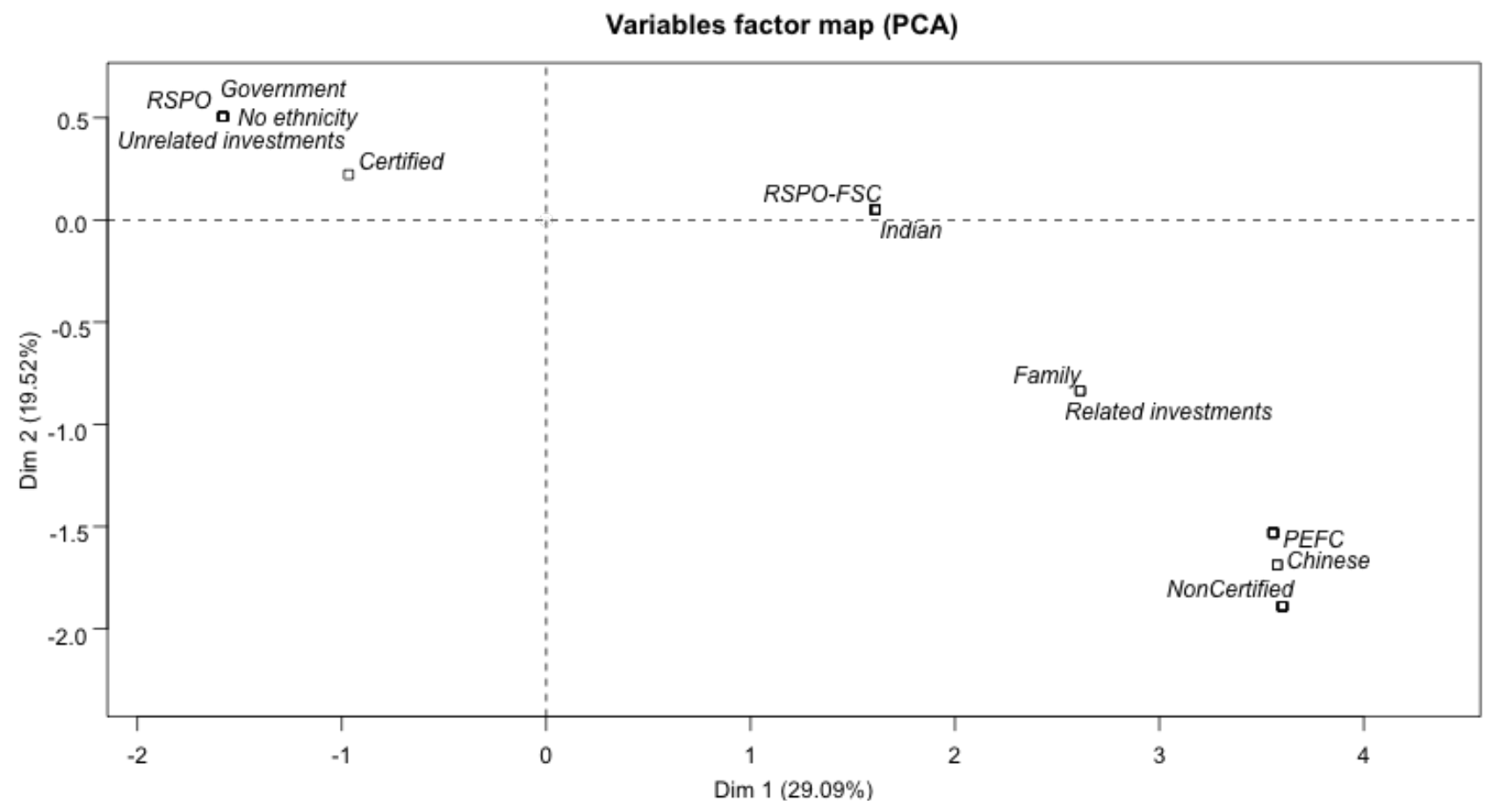

Figure 4. Factor map of environmental commitment proxies for the companies belonging to WTK, Ta Ann, Olam, and Sime Darby transnationals.

We found that $97 \%$ of the specific variability with regard to the uptake of ecocertification in our data set is explained by the first two dimensions. In other words, the amount of listed capital, ownership structure, investment strategies, and flexibility are the overwhelming determinants of the environmental behavior and thus commitment for WTK, Ta Ann, Olam and Sime Darby.

Firstly, $79 \%$ of the environmental behavior is influenced by the following factors. Only the transnationals with more than USD one billion of listed capital appear to have a clear commitment to certification of oil palm plantations, and to the Forest Stewardship Council scheme in the case of Olam. For transnationals, a capital ranging between USD 70 million and USD 90 million, although still substantial, appears to be below a threshold at which there is little incentive for them to commit to environmental sustainability. The transnationals with listed capital over USD one billion and a clear environmental commitment are also those which have a relatively high degree of government involvement: $68 \%$ of Sime Darby shares and 14\% of Olam, respectively. The policies of their respective governments could be decisive in pushing these transnationals towards more sustainable practices. Similarly, the investment strategy related to diversification tends to correlate with a lack of environmental ecocertification. However, this tendency is less clear as Olam has oil palm and forest certifications, even if the management patterns of Olam are not significantly distinct from WTK and Ta Ann (see Figure 3). This specificity of Olam is reflected by the fact that the third dimension of the Principal Component Analysis describes the singularity of Olam (see Table 6). Unlike in classical econometrics, where negative signs imply negative correlations, the negative sign of variables in Principal Component Analysis (see Table 6) do not relate to the strength of their correlation. The absolute value of environmental factors is very high for dimension 1, which denotes a very high correlation. The average cross-shareholding is also highly correlated with this dimension but with an inverted sign: The positive and negative signs mean that these two groups of variables are opposed by 
dimension 1. The same analysis performed with another software could give inverted signs but identical correlations, still showing how dimension 1 opposes the variables.

Table 6. Results of the Principal Components Analysis of ownership, financial and economic factors in relation to the environmental commitment of WTK, Ta Ann, Olam and Sime Darby transnationals.

\begin{tabular}{lccc}
\hline & Dim.1 & Dim.2 & Dim.3 \\
\hline Eigenvalue & 5.527 & 3.709 & 2.312 \\
Percentage of variance & 29.09 & 19.52 & 12.16 \\
Cumulative percentage of variance & 29.09 & 48.61 & 60.78 \\
\hline Contributions & Dim.1 & Dim.2 & Dim.3 \\
\hline Environmental commitment factors & $(-) 14.26$ & $(+) 04.88$ & \\
Proportion of shareholders to subsidiaries & $(+) 13.92$ & $(-) 03.69$ & \\
Hierarchy index & $(-) 12.98$ & & \\
Average ownership tier & $(-) 08.37$ & & $(+) 14.98$ \\
Average cross-shareholding & $(+) 05.27$ & & $(+) 27.52$ \\
Average ownership tier & $(+) 05.19$ & & \\
Number of subsidiaries & & $(+) 15.52$ & \\
Cross-shareholding coefficient & & & $(+) 09.31$ \\
Shareholding stress (decision delay, transact. cost) & & $(+) 12.64$ & \\
Ownership structure diameter & & & $(+) 38.90$ \\
\hline & Dim.1 & Dim.2 & Dim.1 + Dim.2 \\
\hline \% of eigenvalues of env. commitment factors & $78.83 \%$ & $18.11 \%$ & $96.94 \%$ \\
\hline High correlations with qualitative factors & Dim.1 $\left(R^{2}\right)$ & Dim.2 $\left(R^{2}\right)$ & \\
\hline Certification & 0.81 & 0.19 & \\
Listed capital & 0.81 & 0.19 & \\
Government $v s$. Family control & 0.81 & 0.19 & \\
No ethnicity $v s$. Ethnicity & 0.81 & 0.19 & \\
Investment strategy & 0.75 & 0.11 & \\
RSPO or not & 0.55 & 0.18 & \\
\hline
\end{tabular}

Unlike in classical econometrics were negative signs imply negative correlations, the negative sign of variables in Principal Component Analysis (see Table 6) do not relate to the strength of their correlation. The absolute value of environmental factors is very high for dimension 1, which denotes a very high correlation. The average cross-shareholding is also highly correlated with this dimension but with an inverted sign: The positive and negative signs mean that these two groups of variables are opposed by dimension 1 . The same analysis performed with another software could give inverted signs but identical correlations, still showing how dimension 1 opposes the variables.

Secondly, $18 \%$ of the environmental behavior depends on how the transnationals are managed internally. The less pyramidal the organizational structure, with on average fewer subsidiaries per company and faster decision-making processes, the less they will tend to display environmental commitment. In other words, the more the companies tend to be adaptive and flexible, the less they tend to invest in sustainability. This confirms the fundamental dialectic of short-term versus long-term, which is reflected in the organization of the transnationals in Asia as well as outside Asia [69,70]. In the case of Southeast Asia, this calls for some pessimism because the literature amply confirms that the 
intrinsic nature of Asian conglomerates tend to be extremely adaptive and flexible, thus probably less inclined towards long-term sustainability concerns.

In March 2013, the Norwegian Government Pension Fund Global released its 2012 Annual Report announcing that it had sold its stakes in 23 of the world's largest palm oil companies (a total divestiture of USD 314 million), reducing its investments in the Indonesian and Malaysian palm oil industry by over $40 \%$. Several palm oil producers were excluded from the portfolio because their long-term business model was deemed unsustainable $[9,10]$.

\section{Discussion}

The fact that $97 \%$ of the environmental behavior of Southeast Asian agribusiness transnationals is influenced by the amount of listed capital, ownership structure, adaptability and flexibility. This implies that $3 \%$ or less is explained by market mechanisms. This consideration certainly draws attention to the fact that Southeast Asian agribusiness transnationals target, in particular, the markets of emerging countries whilst specializing in South-South exchanges. Their exposure to eco-sensitive markets is generally low. This is especially true when considering tropical timber trade: The relatively eco-sensitive Western world represents less than $6 \%$ of the world consumption of tropical timbers. Conversely, the Western world represents at least one third of the world market for palm oil, which could also account for the reasons pushing Sime Darby and Olam to commit to the Round Table on Sustainable Palm Oil. But clearly this is not enough for Ta Ann and WTK. Indeed at the scale of the ultimate shareholders of such transnationals, the Oil Palm sector is only one sector among others. Unfortunately, the time frame of the study did not allow for a consolidation of the relative size of the various transnationals' investments in various sectors both in comparison to each other and in comparison to the other sectors in their particular portfolios. The next steps of the research will explore how these various sectors relate to each other, and what it means in terms of financial investments and risks.

Even if the palm oil sector is an extremely profitable one (as shown in the accounts of a transnational such as Ta Ann), the marketing and assumed price advantages of adopting eco-certification might not be worth the organizational costs when compared to the need to preserve flexibility and adaptability. In contrast, Sime Darby is more hierarchical organization that is more exposed to issues of a political nature, and hence, its managers might not perceive a greater commitment to environmental sustainability as a major constraint. This still does not explain, however, why Olam, a big transnational in terms of capital, but one that retains a high degree of flexibility like Ta Ann and WTK and commitments to both oil palm and forest certification.

It could well be that Olam and Sime Darby, which have higher exposure of their stocks in the mass market (in relative or absolute figures), are more sensitive to global environmental campaigns. In 2013, Olam's accountability practices were negatively commented on in the media, and it triggered a spectacular fall in share values on the stock exchange. Negative environmental campaigns by the media can have huge impacts that can push smallholders to sell, causing similar falls. This could be a concern for transnationals such as Sime Darby and Olam, if their mass smallholders are already eco-sensitive. Conversely, transnationals with ownership structures distinguished by a higher degree of flexibility, adaptability and some degree of risk management, and with a much lower proportion of 
smallholders per company, may commit less to environmental sustainability. This happens except in countries where national and local government institutions are able to effectively govern compliance with environmental policies. One of the very flexible transnationals, Ta Ann, has a company certified under the chain of custody of the Programme for the Endorsement of Forest Certification (PEFC). It buys its raw material from forests managed by Forestry Tasmania, a Government Enterprise certified under the Australian Forest Standard, which is endorsed by PEFC. This situation imposes itself onto the company, as a governance framework to which it adapts. A proper analogy would be that this kind of Southeast Asian transnational adapts to any institutional context, as a liquid adopts the shape of its container.

Furthermore, our findings have far reaching implications when considering the various efforts to engage the private sector to promote forest sustainability, and the failure to do so by relying simply on market-based tools, as discussed in the Introduction. These findings do not imply that norms and ecocertification standards are not useful and hence, should be scrapped. They may be necessary to prove to interested consumers, investors, or any other concerned groups that some environmental norms or procedures are followed and respected. The network analysis of corporate structures showed that the control of transnationals can be located quite far from their flagship companies. This implies that the stakeholders, who want to debate with these transnationals, or to have an influence on them, should be very careful with whom they engage, and at which level. Private market-based regulatory tools, as discussed in the Introduction, are not effective at the scale where the key determinants of corporate behavior apply for Southeast Asian transnationals, and most probably, other South-South transnationals [69]. The best approach would, nevertheless, be to directly engage the ultimate shareholders. How to engage them remains an open question, and this creates exciting perspectives for new themes of research. Such an approach would critically depend on how meaningful it would be for the overall strategy of the rest of the business group, with all its interlinked sectors.

Additional research needs to investigate the relationships between necessary competiveness, and long-term patrimonial issues, or the intergenerational transmission of "sustainable" businesses, as perceived by the families that control Southeast Asian transnationals. We also found that the complexity ownership structures is linked to the need for flexibility and adaptability. Within the context of more or less high "country risks", business groups are involved in cut-throat competition and face absolute imperatives for flexibility and adaptability. It might be an economic utopia to expect them to take over from failing governments, in terms of their environmental commitments. The imperatives of flexibility and adaptability and opaque ownership structures do not mean that the concepts of accountability and sustainability are not negotiable with Southeast Asian transnationals. On the contrary, these imperatives and structures are clearly instruments for long-term patrimonial issues and intergenerational family ethics in unstable economic or political environments. The literature on ethnic, diasporic and family businesses amply demonstrates that sustainability is at the core of the organization and strategies of Southeast Asian transnationals. But this particular type of sustainability is an economic and profit-motivated one, designed to ensure prosperity of the same kinship group over several generations. Several examples exist, which demonstrate that these transnational entrepreneurs commit entirely to the next generation of the controlling family [25,28]. Finally, for the stakeholders who would like to engage the private sector in order to promote forest 
sustainability, the challenge would then be: How do we make environmental and family business sustainability coincide?

\section{Conclusions}

Ownership structures definitely influence corporate strategies. Intertwined ownership structure is an intrinsic feature of the Southeast Asian transnationals analyzed here. It enables them to decide to quit a market as easily as they decide to adapt to new economic conditions (such as more or less demand for sustainable products). They constantly choose between various relative transaction or organization costs. The extremely intertwined corporate structures appear to be a fundamental adaptation to long-term economic and political country risks and unpredictable conditions. We found that ownership structures reflect clear differences in flexibility, control and transaction costs, but not in ethnicities. Furthermore, capital and its control, ownership structure and flexibility explain $97 \%$ of the environmental behavior of the transnationals studied. However, the data set has some weaknesses. Despite covering 931 companies, only four transnationals were compared. Some uncertainties remain regarding some details of the mechanisms of corporate governance of agribusiness transnationals in Southeast Asia. A larger number of transnationals with various sets of parameters should be studied to draw additional conclusions on the role of governments, investment strategies, or the mass of stock exchange smallholders in shaping or influencing environmental corporate governance. Further research should explore how the various industrial sectors of the transnationals relate to each other, and what it means in terms of financial investments and risks. Nevertheless, the implications of the results to stakeholders who would like to engage Southeast Asian corporations in order to promote forest sustainability are that they should not limit themselves to using market-based tools, but should engage with the ultimate shareholders at the scale where corporate strategies are determined. The challenge is to answer the question: How do we make environmental and family business sustainability coincide?

\section{Acknowledgments}

CIFOR, member of the CGIAR "Research Programme 6 Forests, Trees and Agroforestry", as well as CIRAD, Universiti Putra Malaysia (INTROP), and the ANR SPOP project co-funded the study, which leads to this paper.

\section{Author Contributions}

Jean-Marc Roda and Rafael Palhiarim Tobias designed the experimental work. Norfaryanti Kamaruddin, Rafael Palhiarim Tobias and Jean-Marc Roda performed the data collection and analysis. Norfaryanti Kamaruddin rearranged the materials and analysis results. Jean-Marc Roda wrote the paper.

\section{Conflicts of Interest}

The authors declare no conflict of interest. 


\section{References}

1. Rametsteiner, E.; Simula, M. Forest certification-An instrument to promote sustainable forest management? J. Environ. Manag. 2003, 67, 87-98.

2. Auld, G.; Gulbrandsen, L.H.; McDermott, C.L. Certification schemes and the impacts on forests and forestry. Annu. Rev. Environ. Resourc. 2008, 33, 187-212.

3. Dauvergne, P. Corporate power in the forests of the Solomon Islands. Pac. Aff. 1999, 71, 524-546.

4. Durst, P.B.; McKenzie, P.J.; Brown, C.L.; Appanah, S. Challenges facing certification and eco-labelling of forest products in developing countries. Int. For. Rev. 2006, 8, 193-200.

5. Dauvergne, P. Globalisation and deforestation in the Asia-Pacific. Environ. Polit. 1998, 7, 114-135.

6. Douglas, I. The local drivers of land degradation in South-East Asia. Geogr. Res. 2006, 44, 123-134.

7. McCarthy, J.; Gillespie, P.; Zen, Z. Swimming upstream: Local Indonesian production networks in "globalized" palm oil production. World Dev. 2012, 40, 555-569.

8. Murphy, S.; Burch, D.; Clapp, J. Cereal Secrets: The World's Largest Grain Traders and Global Agriculture; Hobbs, J., Ed.; Oxfam International: Oxford, UK, 2012.

9. Anonymous. Government Pension Fund Global-Annual Report 2012; Norges Bank Investment Management (NBIM): Oslo, Norway, 2013.

10. Gnych, S. Norway's Government Pension Fund Divests from Palm Oil Producers; Center for International Forestry Research: Bogor, Indonesia, 2013.

11. Amanor, K.S. Global landgrabs, agribusiness and the commercial smallholder: A West African perspective. In Proceedings of the International Conference on Global Land Grabbing, Brighton, UK, 6-8 April 2011; pp. 1-35.

12. Mol, A.P.J. China's ascent and Africa's environment. Global Environ. Change 2011, 21, 785-794.

13. Dauvergne, P.; Neville, K.J. Forests, food, and fuel in the tropics: The uneven social and ecological consequences of the emerging political economy of biofuels. J. Peasant Stud. 2010, 37, 631-660.

14. Butler, R.; Laurance, W. New strategies for conserving tropical forests. Trends Ecol. Evol. 2008, 23, 469-472.

15. Coase, R.H. The nature of the firm. Economica 1937, 4, 386-405.

16. Jensen, M.C.; Meckling, W.H. Theory of the firm: Managerial behavior, agency costs, and ownership structure. J. Financ. Econ. 1976, 3, 305-360.

17. Porter, M.E. Competitive Strategy: Techniques for Analyzing Industries and Competitors; Free Press: Cambridge, UK, 1980.

18. Porter, M.E. From competitive advantage to corporate strategy. Harvard Bus. Rev. 1987, 65, 117-151.

19. Chandler, A.D., Jr. The M-form: Industrial groups, American style. Eur. Econ. Rev. 1982, 19, 3-23.

20. Almeida, H.V.; Wolfenzon, D. A theory of pyramidal ownership and family business groups. J. Financ. 2006, 61, 2637-2680.

21. Todeva, E. Business Networks: Strategy and Structure; Routledge Studies in Business Organization and Networks, Routledge: London, UK, 2006.

22. De Masi, G.; Gallegati, M. Bank-firms topology in Italy. Empir. Econ. 2012, 43, 851-866.

23. La Porta, R.; Lopez de Silanes, F.; Shleifer, A. Corporate ownership around the world. J. Financ. 1999, 54, 471-517. 
24. Masulis, R.W.; Pham, P.K.; Zein, J. Family business groups around the world: financing advantages, control motivations, and organizational choices. Rev. Financ. Stud. 2011, 24, 3556-3600.

25. Weidenbaum, M.L.; Hughes, S. The Bamboo Network: How Expatriate Chinese Entrepreneurs Are Creating a New Economic Superpower in Asia; Free Press: New York, NY, 1996.

26. Crawford, D. Chinese capitalism: Cultures, the Southeast Asian region and economic globalisation. Third World Q. 2000, 21, 69-86.

27. Rauch, J.E.; Trindade, V. Ethnic Chinese Networks in International trade. Rev. Econ. Stat. 2002, $84,116-130$.

28. Yan, J.; Sorenson, R. The effect of confucian values on succession in family business. Fam. Bus. Rev. 2006, 19, 235-250.

29. Leblang, D. Familiarity breeds investment: Diaspora networks and international investment. Am. Polit. Sci. Rev. 2010, 104, 584-600.

30. Tsai, L.-C.; Chiou, S.-L.; Wu, S.-J.; Young, C.-S. Corporate ownership structure and the value relevance of family executives' external directorships. Asia Pac. Manag. Rev. 2010, 15, 223-249.

31. Cadene, P.; Vidal, D. Webs of Trade: Dynamics of Business Communities in Western India; Cadene, P., Vidal, D., Eds.; Manohar Publishers and Distributors: New Delhi, India, 1997.

32. Bhattacharya, J. Beyond the myth: Indian business communities in Singapore; Institute of Southeast Asian Studies: Singapore, 2011.

33. Ferris, S.P.; Kim, K.A.; Kitsabunnarat, P. The costs (and benefits?) of diversified business groups: The case of Korean chaebols. J. Bank. Financ. 2003, 27, 251-273.

34. Almeida, H.; Park, S.Y.; Subrahmanyam, M.G.; Wolfenzon, D. The structure and formation of business groups: Evidence from Korean chaebols. J. Financ. Econ. 2011, 99, 447-475.

35. Ito, T.; Niki, E.; Takida, R.; Mehta, R.; Passerini, K.; Sakamoto, M. Transactions and cross shareholdings in Mazda's Keiretsu: A centrality analysis. Artif. Life Robot. 2011, 16, 297-300.

36. Weimer, J.; Pape, J. A taxonomy of systems of corporate governance. Corp. Gov. 1999, 7, 152-166.

37. Morck, R.; Wolfenzon, D.; Yeung, B. Corporate governance, economic entrenchment, and growth. J. Econ. Lit. 2005, 43, 655-720.

38. Gilson, R.J. Controlling shareholders and corporate governance: Complicating the comparative taxonomy. Harvard Law Rev.2006, 119, 1641-1679.

39. Chung, H.-M.; Chan, S.-T. Ownership structure, family leadership, and performance of affiliate firms in large family business groups. Asia Pac. J. Manag. 2012, 29, 303-329.

40. Chung, H.-M. The role of family management and ownership on semi-globalization pattern of globalization: The case of family business groups. Int. Bus. Rev. 2014, 23, 260-271.

41. Cashore, B.; van Kooten, G.C.; Vertinsky, I.B.; Auld, G.; Affolderbach, J. Private or self-regulation? A comparative study of forest certification choices in Canada, the United States and Germany. For. Policy Econ. 2003, 7, 53-69.

42. Araujo, M.; Kant; S.; Couto, L. Why Brazilian companies are certifying their forests?. For. Policy Econ. 2009, 11, 579-585.

43. Rugman, A.M.; Verbeke, A. Corporate strategy and international environmental policy. J. Int. Bus. Stud.1998, 29, 819-833.

44. Krebs, V. Visualizing human networks. Release 1996, 2, 1-25. 
45. De Nooy, W.; Mrvar, A.; Batagelj, V. Exploratory Network Analysis with Pajek; Cambridge University Press: Cambridge, UK, 2007; Volume 27.

46. Glattfelder, J.B. Ownership Networks and Corporate Control: Mapping Economic Power in a Globalised World. Ph.D. Thesis, Technische Hochschule ETH Zürich, Zurich, Switzerland, 2010.

47. Vitali, S.; Glattfelder, J.B.; Battiston, S. The network of global corporate control. PLoS ONE. 2011, 6, e25995.

48. Dietzenbacher, E.; Temurshoev, U. Ownership relations in the presence of cross-shareholding. J. Econ. 2008, 95, 189-212.

49. D’Errico, M.; Grassi, R.; Stefani, S.; Torriero, A. Shareholding networks and centrality: An application to the Italian financial market. In Networks, Topology and Dynamics; Springer: Berlin, Germany, 2009; Volume 613, pp. 215-228.

50. Grassi, R. Vertex centrality as a measure of information flow in Italian Corporate Board Networks. Phys. A 2010, 389, 2455-2464.

51. Greenpeace. How the Palm Oil Industry is Cooking the Climate; Greenpeace International: Amsterdam, the Netherlands, 2007.

52. Greenpeace. Palm Oil's New Frontier: How Industrial Expansion Threatens Africa's Rainforests; Greenpeace International: Amsterdam, the Netherlands, 2012.

53. CDP. The Commodity Crunch: Value at Risk from Deforestation; Carbon Disclosure Project: London, UK, 2013.

54. Lawson, S.; Blundell, A.; Cabarle, B.; Basik, N.; Jenkins, M.; Canby, K. Consumer Goods and Deforestation: An Analysis of the Extent and Nature of Illegality in Forest Conversion for Agriculture and Timber Plantations; Forest Trend Report Series; Forest Trends: Washington, DC, USA, 2014.

55. Bastian, M.; Heymann, S.; Jacomy, M. Gephi: An open source software for exploring and manipulating networks. In Proceedings of the Third International ICWSM Conference; San Jose, CA, USA, 17-20 May 2009.

56. Smoot, M.E.; Ono, K.; Ruscheinski, J.; Wang, P.-L.; Ideker, T. Cytoscape 2.8: New features for data integration and network visualization. Bioinformatics 2011, 27, 431-432.

57. Tekušová, T.; Kohlhammer, J. Visual analysis and exploration of complex corporate shareholder networks. In Proceedings of the Electronic Imaging, Science and Technolgy, San Jose, CA, USA, 28-29 January 2008; Volume 6809, p. 68090F.

58. Hanneman, R.A.; Riddle, M. Introduction to Social Network Methods; University of California: Riverside, CA, USA, 2005.

59. Borner, K.; Sanyal, S.; Vespignani, A. Network science. Annu. Rev. Inf. Sci. Technol. 2007, 41, 537-607.

60. Scardoni, G.; Petterlini, M.; Laudanna, C. Analyzing biological network parameters with CentiScaPe. Bioinformatics 2009, 25, 2857-2859.

61. Greer, J.; Kenny, B. Greenwash: The Reality Behind Corporate Environmentalism; Third World Network: Penang, Malaysia, 1998.

62. Lippert, I. Greenwash. In Green Culture: An A-to-Z Guide; Wehr, K., Ed.; Sage Publications, Inc.: Thousand Oaks, CA, USA, 2011. 
63. Papargyropoulou, E.; Padfield, R.; Harrison, O.; Preece. C.; The rise of sustainability services for the built environment in Malaysia. Sustain. Cities Soc. 2012, 5, 44-51.

64. Chen, K.-C. The ethnic Chinese style of corporate innovation. In Proceedings of PICMET 2008. Portland International Conference on Management of Engineering and Technology, Cape Town, South Africa, 27-31 July 2008; pp. 486-496.

65. Li, J.; Young, M.N.; Tang, G. The development of entrepreneurship in Chinese communities: An organizational symbiosis perspective. Asia Pac. J. Manag. 2010, 29, 367-385.

66. Dahles, H. On (mis-)conceptions of culture as a vehicle of business success: Singapore Chinese investment strategies after failing in China. East Asia 2007, 24, 173-193.

67. Jacobsen, M. Doing business the Chinese way? On Manadonese Chinese, entrepreneurship in North Sulawesi. Copen. J. Asian Stud. 2007, 24, 105-136.

68. Roda, J.-M. On the nature of intergenerational and social networks in the African forest sector: The case of Chinese, Lebanese, Indian \& Italian business networks. In Governing Africa's Forests in a Globalized World; German, L.A., Karsenty, A., Tiani A.-M., Eds.; Earthscan: London, UK, 2009; pp. 1-23.

69. Drori, I.; Honig, B.; Wright, M. Transnational entrepreneurship: An emergent field of study. Entrep. Theory Pract. 2009, 33, 1001-1022.

70. Giansoldati, M.; Pauluzzo, R. The international evolution of Italian and Chinese districts: What role for lead firms? Transit. Stud. Rev. 2011, 18, 471-486.

(C) 2015 by the authors; licensee MDPI, Basel, Switzerland. This article is an open access article distributed under the terms and conditions of the Creative Commons Attribution license (http://creativecommons.org/licenses/by/4.0/). 